\title{
Effect of Serial Passage on Growth Kinetics, Biological Properties, and Differentiation into Adipocytes of Human Wharton's Jelly-Derived Mesenchymal Stem Cells
}

\author{
Rizal Rizal, ${ }^{1}$ Wahyu Setia Widodo, ${ }^{2}$ Satrio Haryo Benowo Wibowo, ${ }^{2}$ Ubaydillah Zedd Munshy ${ }^{2}$ \\ ${ }^{1}$ Biomedical Engineering, Department of Electrical Engineering, Faculty of Engineering, Universitas Indonesia, \\ Jakarta, Indonesia, ${ }^{2}$ Biomolecular and Biomedical Research Center, Aretha Medika Utama, Bandung, Indonesia
}

\begin{abstract}
Early passges of human Wharton's jelly-derived mesenchymal stem cells (hWJMSCs) have been suggested by various studies; however, the effect of serial passaging has not been well defined. This study aimed to investigate the effect of serial passage on the growth kinetics, biological properties and differentiation into adipocytes on hWJMSCs. This study was conducted from April to December 2014 to evaluate the hWJMSCs growth kinetics at passage 6 (P6) and P12 by calculating proliferation rate, population doubling time (PDT), and cumulative population-doubling levels (CPDL) using 3-(4,5-dimethylthiazol-2-yl)-5-(3-carboxymethoxyphenyl)-2-(4sulfophenyl)-2H-tetrazolium MTS assay kit. The cells biological properties were characterized using flow cytometry analysis followed by measuring the differentiation into adipocytes in extensive culture using Oil Red 0 staining after induction. An independent sample t-test was applied to analyze the differences between groups using IBM SPSS Statistics Version 22 with a p<0.05 considered significant. The growth kinetics assay showed the cells at P6 had a higher proliferation rate, CPDL, and faster PDT compared to the cells at P12 ( $<<0.05)$. Data from expression of MSCs surface markers showed that the cells retained their biological properties at both passages but decreased at P12 $(\mathrm{p}<0.05)$. The formation of intracellular lipid droplets was also observed at both passages under adipogenic induction. However, the content of oil red 0 extracted-cells decreased at P12 $(\mathrm{p}<0.05)$. The hWJMSCs decreased their growth kinetics, biological properties, and differentiation into adipocytes as a result of serial passage. This finding might be valuable for treating degenerative diseases using cell-based therapy.
\end{abstract}

Key words: Differentiation into adipocytes, serial passage, stem cells, Wharton's jelly

\section{Pengaruh Pasase Berseri terhadap Kinetika Pertumbuhan, Karakteristik Biologis, dan Diferensiasinya Menjadi Adipocytes yang Berasal dari Jaringan Wharton's Jelly-Sel Punca Mesenkim}

\begin{abstract}
Abstrak
Penelitian tentang sel punca mesenkim yang berasal dari jaringan Wharton's Jelly manusia (hWJMSCs) hanya disarankan penggunaanya pada pasase awal. Pengaruh pasase berseri terhadap karakteristik sel hWJMSCs belum banyak diuraikan dengan baik. Penelitian ini bertujuan untuk mengetahui efek dari pasase berseri terhadap kinetika pertumbuhan, sifat biologis dan diferensiasi menjadi adipocytes dari sel hWJMSCs. Penelitian ini dilakukan di Laboratorium Fisiologi, Fakultas Kedokteran, Universitas Gadjah Mada dan Aretha Medika Utama, Biomolecular and Biomedical Research Center, dari bulan April sampai Desember 2014. Kinetika pertumbuhan sel hWJMSCs pada P6 dan P12 dievaluasi dengan menghitung laju pertumbuhan sel, population doubling time (PDT), dan cumulative population-doubling levels (CPDL) menggunakan uji MTS. Sifat biologis sel dikarakterisasi menggunakan flowsitometri dengan mengukur ekspresi penanda permukaan CD90, CD105, CD73, dan CD44. Kemampuan diferensiasinya menjadi adipocytes diukur menggunakan pewarnaan Oil Red 0 setelah induksi mendium diferensiasi adipogenik. Uji kinetika pertumbuhan sel menunjukkan sel-sel di P6 memiliki tingkat proliferasi dan CPDL yang lebih tinggi dan PDT yang lebih cepat dibanding dengan sel-sel P12 $(\mathrm{p}<0,05)$. Karakterisasi MSCs menunjukkan bahwa sel-sel tersebut mempertahankan sifat biologisnya di kedua pasase tetapi menurun pada P12 $(\mathrm{p}<0,05)$. Jumlah intraseluler lemak pada P12 lebih sedikit dibandingkan pada P6 $(\mathrm{p}<0,05)$. Kinetika pertumbuhan, sifat biologis, dan kemampuan berdiferensiasi menjadi adipocytes dari hWJMSCs menurun sebagai akibat pasase berseri.
\end{abstract}

Kata kunci: Diferensiasi menjadi adipocytes, pasase berseri, sel punca, Wharton's jelly

Corresponding Author: Rizal, Biomedical Engineering, Department of Electrical Engineering, Faculty of Engineering, Universitas Indonesia, Jalan Kampus UI, Kecamatan Beji, Kota Depok, West Java, Indonesia, Email: rizal04@ui.ac.id 
Rizal, et al: Effect of Serial Passage on Growth Kinetics, Biological Properties, and Differentiation into Adipocytes of Human Wharton's Jelly-Derived Mesenchymal Stem Cells

\section{Introduction}

Wharton's jelly from human umbilical cord is a promising source of mesenchymal stem cells (MSCs) that offers therapeutic use for treating degenerative diseases. ${ }^{1}$ However, these cells could change their morphological and surface marker expression based on the source of MSCs, age-dependent donor-to-donor variation, and extensive culture. ${ }^{2}$ MSCs are primary cells (non-immortalized cells) that have a limited lifespan and experience decreased multilineage differentiation after undergoing serial passaging. ${ }^{3}$ Ideally, MSCs should be able to maintain their differentiation ability while they are in a long-term culture and during extensive serial passaging. ${ }^{4}$ However, the biological function of MSCs in culture can be changed during passaging due to overconfluent and cell-to-cell contact affecting the genetic and epigenetic alterations. ${ }^{5}$

Adipogenesis is a process where stem cells differentiate into adipocytes, which involves several genes such as proliferator-activated receptor-ÿ (PPAR) as the main gene in adipogenic differentiation ${ }^{6}$; lipoprotein lipase (LPL) which is involved in lipid metabolism and transport ${ }^{7}$; fatty acid-binding protein (aP2) for cholesterol trafficking as well as inflammatory activity; and so on. Those cooperating genes will lead to changes in morphological and biochemical characteristics into mature adipocytes. ${ }^{4}$

Passaging or sub-culturing of MSCs is necessary to obtain adequate cell numbers for clinical applications. Osteogenic and adipogenic differentiation of adipose-derived mesenchymal stem cells (AT-MSCs) may be able to be maintained through $10-15$ passages but their differentiation capacity decline after serial passaging. ${ }^{9}$ However, a different study showed that adipogenic differentiation of MSCs is variable after serial passaging. ${ }^{10}$ Thus, it is still unclear whether MSCs can maintain their differentiation ability in an extensive culture.

Therefore, to demonstrate the effect of serial passaging on differentiation into adipocytes of hWJMSCs, in this study, the growth kinetics, biological properties from different passages (P6 and P12), and their adipogenic ability were investigated and compared in passages. Data obtained could be used to closely evaluate the efficiency of differentiation into adipocytes of hWJMSCs in a long-term culture.

\section{Methods}

This study was conducted in Physiology Laboratory, Faculty of Medicine, Universitas Gajah Mada from April to September 2014. The Ethical Clearance was issued by the Medical and Health Research Ethics Committee (MHREC)Faculty of Medicine, Universitas Gajah Mada (No. KE/FK/1132/EC).

hWJMSCs were obtained from a previous study. ${ }^{11}$ The cells were isolated by explant methods. All UCs were washed with sterile phosphate-buffered saline (PBS) $1 x$ to remove of the blood cells from UCs and the UCs were then placed into a transport medium containing PBS 1x (Gibco, Invitrogen, USA), 1\% (v/v) penicilinstreptomicin (Gibco, Invitrogen, USA), 1\% amphotericin $-\beta(v / v)$ (Gibco, Invitrogen, USA), and $20 \mathrm{ug} / \mathrm{ml}$ gentamicine (Gibco, Invitrogen, USA) and were stored at $4^{\circ} \mathrm{C}$ for less than $24 \mathrm{~h}$ before tissue processing. Briefly, blood vessels (artery and venous) were longitudinally dissected from the UC, separating them from the WJ tissue. The WJ tissue was then cut into $1-2 \mathrm{~cm}^{3}$ explant fragments and washed with sterile PBS. The fragments were plated on $60 \mathrm{~mm}$ tissue culture plates (MCD110090) and cultured in an hWJMSCs complete growth medium containing MEMalpha (Gibco, Invitrogen, Canada) supplemented with $10 \%(\mathrm{v} / \mathrm{v})$ fetal bovine serum (Gibco, Invitrogen Corporation, Grand Island, NY, USA), $1 \%(\mathrm{v} / \mathrm{v}$ ) pen-strep (Gibco, Invitrogen, USA), 1\% (v/v) amphotericin- $\beta$ (Gibco Invitrogen, USA), and $20 \mathrm{mg} / \mathrm{ml}$ gentamicine (Gibco Invitrogen, USA). Cultures were incubated in a humidified atmosphere with $5 \% \mathrm{CO}_{2}$ at $37^{\circ} \mathrm{C}$. The medium was replaced every 3 days. After the cells grew, these cells were cultured and expanded in the hWJMSCs complete growth medium.

To measure the growth kinetics of hWJMSCs, the hWJMSCs Passage 6 and Passage 12 (P6 and P12) were plated at a density of $5.5 \times 10^{3}$ cells $/ \mathrm{cm}^{2}$ and were seeded into six-well plates (Thermo, Massachusetts, USA) supplemented with $2 \mathrm{~mL}$ of growth medium. Cell proliferation was calculated at day 3, 6, 9 by 3-(4,5-dimethylthiazol-2-yl)-5(3-carboxymethoxyphenyl)-2-(4-sulfophenyl)2H-tetrazolium MTS kit (Abcam, Cambridge, United Kingdom) according to the manufacturer's instruction. Afterwards, MTS reagent was added into each well plate in a 10:1 ratio relative to the media and incubated for $3 \mathrm{~h}$ at $37^{\circ} \mathrm{C}, 5 \% \mathrm{CO}_{2}$. Next, $200 \mathrm{~mL}(\mathrm{n}=3)$ was transferred to a $96-$ well plate and the absorbance was measured 
using a spectrophotometer (MultiSkan Go Thermoscientific, Massachusetts, USA) at 490 nm. The population doubling (PD) at P6 and P12 was calculated as described previously, ${ }^{12}$ using the equation of $P D=\log _{2}\left(C_{H} / C_{S}\right)$, where $C_{H}$ is the number of viable cells at harvest and $\mathrm{C}_{\mathrm{S}}$ is the number of cells seeded. The population doubling time (PDT) was calculated using the time interval between cell seeding and harvest divided by the number of PDs for that passage. Cumulative population-doubling levels (CPDLs) were determined from all previous PDs at each passage. All experiments were performed in triplicate.

The surface markers of hWJMSCs (P6 and P12) were evaluated by flow cytometry (Macsquant, Analyzer 10, Beach Road, Singapore). hWJMSCs at $80 \%$ confluence were harvested and dissociated with trypsin-EDTA and centrifuged at 5,000 rpm for 5 minutes. The pellet was resuspended with PBS 1x, FBS and cells were counted with a haemocytometer. Between $1 \times 10^{5}-2 \times 10^{5}$ cells in $500 \mu \mathrm{L}$ PBS cells were stained with appropriate positive surface antibodies of CD90-FITC, CD105-PerCP-Cy5, CD73-APC, and CD44-PE and negative surface antibodies of CD34-PE, CD116-PE, CD19-PE, CD45-PE, and HLA-DR-PE according to manufacturer's protocol (BD stem
flowKit, Becton, USA). Isotype controls were used as the background staining. All experiments were performed in triplicate.

Differentiation into adipocytes was conducted through the following method. Cells (P6 and P12) were plated at a density of $1.1 \times 10^{4}$ cell/ $\mathrm{cm}^{2}$ in four-well plates (Nunc, Thermo Scientific, Massachusetts, USA), grown to confluence, and incubated around 2 days in growth medium at $37^{\circ} \mathrm{C}, 5 \% \mathrm{CO}_{2}$. The cells were then exposed to StemPro Adipogenesis Differentiation Medium (Gibco, Invitrogen, USA) for approximately 21 days. After 3 weeks of culture with fresh medium replacement every 3 days, the cells were fixed with $4 \%$ paraformaldehyde (PFA) for 30 minutes at room temperature and stained using Oil Red 0 (Sigma, Missouri, USA) to examine the intracellular lipid droplets. ${ }^{11}$ Oil Red 0 from stained samples was extracted by adding 500 $\mathrm{ml}$ of isoproponal (Merck, New Jersey, USA) into each well and incubated for 15 minutes. Then, $100 \mathrm{~mL}(\mathrm{n}=3)$ was transferred onto a 96-well plate and the absorbance was then quantified using spectrophotometer (MultiSkan Go Thermoscientific, Massachusetts, USA) at 540 $\mathrm{nm}^{13}$

Data were presented as mean \pm standard deviation (SD). An Independent sample t-test
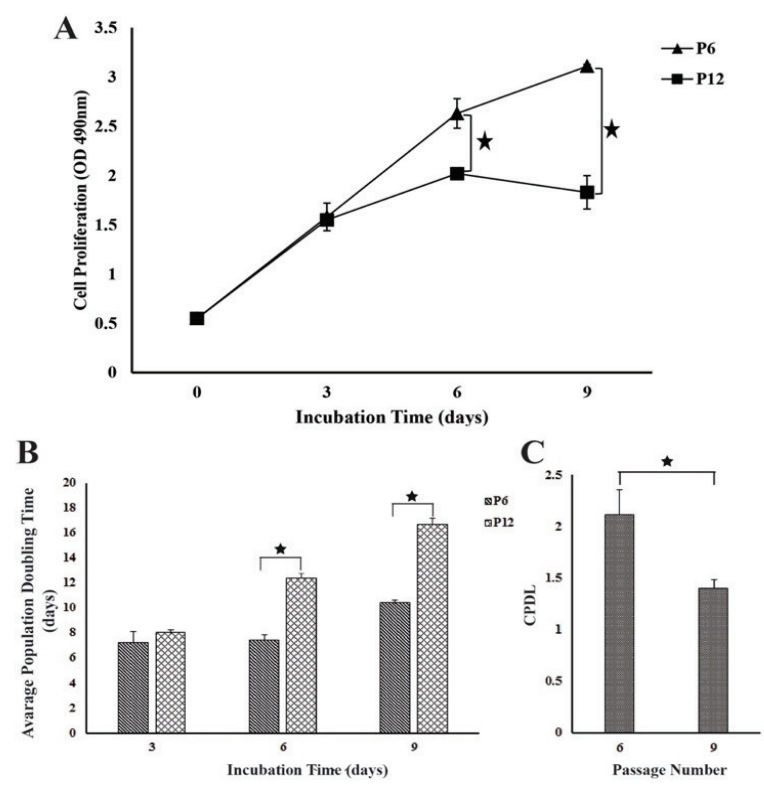

Figure 1 Growth Kinetics of hWJMSCs

(A) Proliferation rate of hWJMSCs at P6 and P12 during 9 day of culture period. (B) Average population doubling time (PDT) at P6 and P12. (C) Cumulative population doubling level (CPDL) at P6 and P12. Bars represent the mean \pm SD. Significant differences were considered when $* \mathrm{p}<0.05$ 
Rizal, et al: Effect of Serial Passage on Growth Kinetics, Biological Properties, and Differentiation into Adipocytes of Human Wharton's Jelly-Derived Mesenchymal Stem Cells
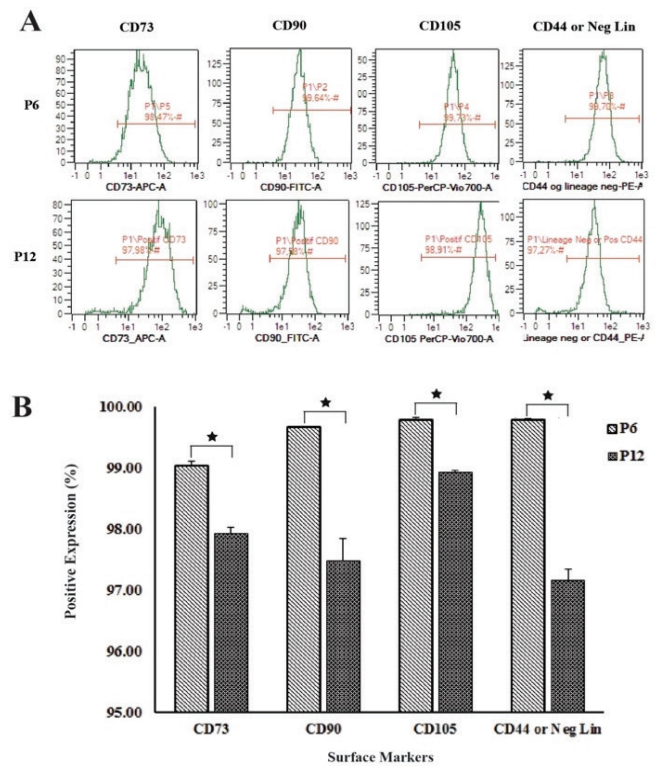

Figure 2 Immunophenotyping of hWJMSCs

(A) Histograms of flow cytometry in which the positive gates percentages shown in green for both passages. (B) Percentage of positive cell surface markers expression (CD73, CD90, CD105, and CD44) at P6 and P12. Bars represent the mean \pm SD. Significant differences were considered when ${ }^{*} \mathrm{p}<0.05$

was performed in order to analyze the differences between groups using IBM SPSS Statistics Version 22. A value of $\mathrm{p}<0.05$ was considered significant.

\section{Results}

Proliferation was assessed for 9 days on day $0,3,6$, and 9 in both passage 6 and 12 after undergoing extensive sub-cultivation. At the beginning of the proliferation assay (day 3), the cells appeared to proliferate at the same number. Then, the growth rate of hWJMSCs in P6 increased significantly compared to P12 on day $6(\mathrm{p}<0.05)$. At the end of the culture period (day 9), significant differences in proliferation were also observed between these two passages in which $\mathrm{P} 6$ rose considerably and P12 declined slightly to around $3.11 \pm 0.02$ and $1.83 \pm 0.17$, respectively (Figure $1 \mathrm{~A}$ ). When referring to the population doubling time (PDT), by day 6 the P6 of hWJMSCs proliferated faster than P9 (Figure 1B). In addition, at the end of culture period, P12 still showed high PDT around 16.63 \pm 0.54 compared to P6 of about $10.38 \pm 0.24(\mathrm{p}<0.05)$, which corresponded to a significant increase in CPDL for P6 rather than for P12 (Figure 1C).

hWJMSCs were examined at P6 and P12 for the expression of cell surface markers commonly used in the characterization of MSCs populations. Cells expressed positive markers for MSCs (CD73, CD90, CD105, and CD44) and lacked the expression of CD34, CD116, CD19, CD45, and HLA-DR in both passages (Figure 2A). However, the pattern of positive surface markers expression decreased significantly at P12 in correlation with the enhancement of serial passage numbers, which was approximately less than 99\%, compared to P6 which was maintained consistently over $99 \%$ for all positive surface markers $(\mathrm{p}<0.05)$ (Figure 2B).

hWJMSCs were cultured for differentiation into adipocytes for 21 days in specific media. It can be seen that intracellular lipid droplets formed in differentiated cells were stained in red colour by Oil Red 0 staining. The differentiated cells in P6 suggested more intense intracellular lipid droplets staining than P12 in which undifferentiated cells were considered as control (Figure 3A). Moreover, the measurement of Oil Red 0 staining content in the differentiated cells at P6 was higher, approximately $0.047 \pm 0.003$, when compared to P12 of differentiated cells of around $0.026 \pm 0.009(\mathrm{p}<0.05)$ (Figure 3B).

\section{Discussion}

Mesenchymal stem cells (MSCs) hold a great promise in treating regenerative diseases due 


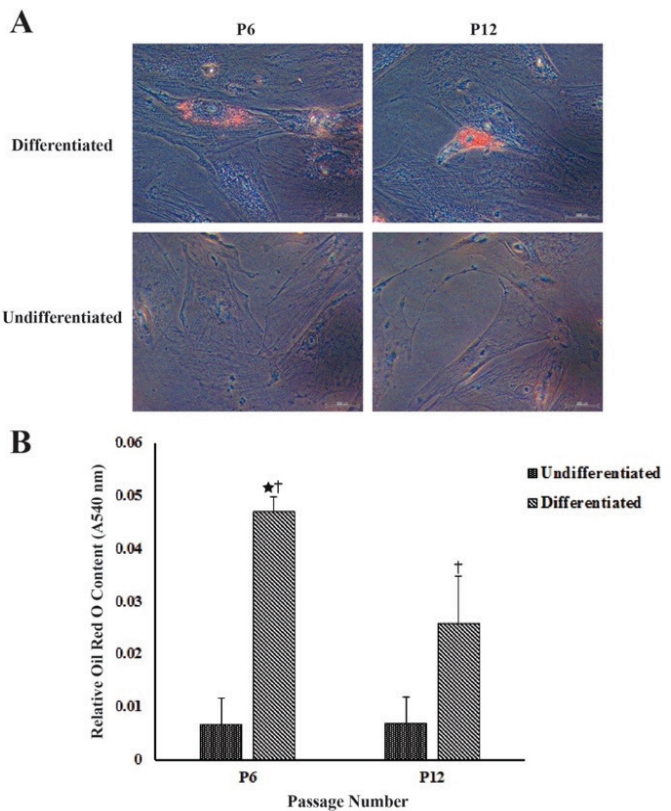

\section{Figure 3 Differentiation into Adipocytes of hWJMSCs}

(A) Comparison of hWJMSCs at P6 and P12 undergoing adipogenesis differentiation by the formation of intracellular lipid droplets stained with Oil Red-0 at 21 days after induction. (B) Quantification of Oil Red-0 content in differentiated and undifferentiated/control cells at both passages. Bars represent the mean \pm SD. Significant differences were considered when ${ }^{*} \mathrm{P}<0.05$ between different passage and ${ }^{\ddagger} \mathrm{p}<0.05$ within the same passage. Magnification 400x. Scale Bars: $200 \mathrm{mM}$

to the fact that they have self-renewal and multipotent differentiation ability. However, the cells must be extensively passaged in order to produce adequate number of cells. In this study, it is suggested that MSCs isolated from human Wharton's jelly tissue are potentially capable of extensive culture up to P12. Nevertheless, the effect of serial passage on hWJMSCs has not been well identified. The cells were able to show differentiation into adipocytes in both passages (P6 and P12).

First, the growth kinetics of hWJMSCs at P6 and P12 were examined in order to characterize the proliferation rate. There was a significant difference in the proliferation rate of P6 and P12 during "the late phase of the culture period". This is consistent with the data obtained that the serial passage affects the increased percentage of senescent cells at P11-20 when compared to the early phase (P2-P10). ${ }^{14}$ In addition, a slowing of population doubling time (PDT) at P12 was found, which might reflect the effect of increasing passage. This result is in line with the finding from a previous study that adipose-derived stem cells (ASCs) have longer doubling times upon further passaging. ${ }^{15}$ On the other hand, cells at P6 retain their PDT during incubation time, suggesting these cells still have self-renewal capacity. In agreement with a previous study, the PDT remains constant until P10. ${ }^{16}$ Furthermore, this result also showed a significant difference in cumulative population doubling level (CPDL) between both passages.

In terms of hWJMSCs surface markers, both passages had still shown the biological properties of MSCs during culture period. However, in the present study, the percentage of positive surface markers (CD73, CD90, CD105, and CD44) in P12 decreased significantly, which was in line with the pattern of declined proliferative ability when compared to P6. In the previous study, the expression of these positive surface markers is high up to P10, contributing to the multipotent differentiation of hWJMSCs. ${ }^{17}$ However, another study suggested that the expression of canine UC-MSCs surface markers (CD44, CD,54, CD61, CD80,, CD90 and Fik-1) is not related to the increased number of passages but CD105 decreases with extensive culture. ${ }^{18}$ Serial passaging also affects the expression of stem cells pluripotent markers (Oct3/4, Nanog and Sox2). Expression of Oct3/4 was decreased with increasing number of sub-passages. In addition, the expression of Nanog and Sox2 was negatively correlated with the number of sub-passage. It was reported that transcription factors such as 
Nanog, Rex1, Fzd9, Oct4, Sox2, and Bst1 genes were essential in pluripotency maintenance as well as self-renewal. ${ }^{19}$

The result of this present study also showed that serial passage influenced hWJMSCs differentiation into adipocytes. The adipogenic differentiation of MSCs can be easily identified by cells morphology in which the cells will convert their shape from fibroblastic cells to spherical shape after induction. ${ }^{4}$ In addition, the formation of oil droplets in the adipogenic medium is also the sign of adipogenesis in hWJMSCs. At both passages (P6 and P12), intracellular oil droplets could be detected after oil red 0 staining. However, the content of Oil Red 0 extracted-cells between both passages was significantly different. The result demonstrated that the cells reduced their differentiation into adipocytes after serial passage. This is also in agreement with previous study that bone marrow-derived hMSCs lose their adipogenic ability at latter passages and are able to undergo osteogenic differentiation due to the expression of bone formation genes. ${ }^{20}$ Moreover, adipogenic differentiation of ASCs could be maintained up to P20 where the expression of adipogenic genes (PPAR-gamma, LPL and aP2) increases significantly at up to P10 and declines at latter passages, affecting the formation of oil droplets. ${ }^{4}$

In conclusion, an extensive culture or serial passage influences the growth kinetics and biological properties of hWJMSCs, which further affects its adipogenic potential. Better understanding of biology and differentiation into adipocytes of hWJMSCs will rise their potential to be successfully used in treating degenerative diseases.

\section{References}

1. Simões IN, Boura JS, dos Santos F, Andrade PZ, Cardoso CM, Gimble JM, et al. Human mesenchymal stem cells from the umbilical cord matrix: Successful isolation and ex vivo expansion using serum-/xeno-free culture media. Biotechnol J. 2013;8(4):448-58.

2. Elkhenany $H$, Amelse $L$, Caldwell $M$, Abdelwahed R, Dhar M. Impact of the source and serial passaging of goat mesenchymal stem cells on osteogenic differentiation potential: implications for bone tissue engineering. J Anim Sci Biotechnol. 2016; $7: 16$.

3. Lian J, Lv S, Liu C, Liu Y, Wang S, Guo X, et al. Effects of serial passage on the characteristics and cardiac and neural differentiation of human umbilical cord Wharton's jellyderived mesenchymal stem cells. Stem Cells Int. 2016;2016:2-12.

4. Safwani WKZW, Makpol S, Sathapan S, Chua $\mathrm{K}$. Impact of adipogenic differentiation on stemness and osteogenic gene expression in extensive culture of human adipose-derived stem cells. Arch Med Sci. 2014;10(3):597606.

5. Nguyen HT, Geens M, Spits C. Genetic and epigenetic instability in human pluripotent stem cells. Hum Reprod Update. 2013;19(2):187-205.

6. Yuan SM, Guo Y, Wang Q, Xu Y, Wang M, Chen HN, Shen WM. Over-expression of PPAR- $\gamma 2$ gene enhances the adipogenic differentiation of hemangioma-derived mesenchymal stem cells in vitro and in vivo. Oncotarget. 2017; 298(70):115817.

7. Moseti D, Regassa A, Kim WK. Molecular regulation of adipogenesis and potential anti-adipogenic bioactive molecules. Int J Mol Sci. 2016;17(1):124

8. Eom J, Feisst V, Ranjard L, Loomes K, Damani T, Jackson-Patel V, Locke M, et al. Visualization and quantification of mesenchymal cell adipogenic differentiation potential with a lineage specific marker. J Vis Exp. 2018; 31(133):e57153.

9. Zhao Y, Waldman SD, Flynn LE. The effect of serial passaging on the proliferation and differentiation of bovine adiposederived stem cells. Cells Tissues Organs. 2012;195(5):414-27.

10. Yang YH, Ogando CR, See CW, Chang TY, Barabino GA. Changes in phenotype and differentiation potential of human mesenchymal stem cells aging in vitro. Stem Cell Res Ther. 2018;9(1):131

11. Rizal R, Kerans FFA, Hermantara R, Herningtyas EH. Isolation, characterization, proliferation, differentiation, and freezethaw survival of human wharton's jelly mesenchymal stem cells from early and late passages. Bioscience Research. 2018;15 (1):392-401.

12. Jin H, Bae Y, Kim M, Kwon SJ, Jeon H, Choi S, Kim S, Yang Y, Oh W, Chang J. Comparative analysis of human mesenchymal stem cells from bone marrow, adipose tissue, and umbilical cord blood as sources of cell therapy. International journal of molecular sciences. 2013;14(9):17986-8001.

13. Ahern BJ, Thomas P, Terkhorn SP, Jackson $\mathrm{K}$ V, Mason NJ, Hankenson KD. Evaluation 
of equine peripheral blood apheresis product, bone marrow, and adipose tissue as sources of mesenchymal stem cells and their differentiation potential. Anim Biol. 2011;72(1):127-33.

14. Lian J, Lv S, Liu C, Liu Y, Wang S, Guo X, et al. Effects of serial passage on the characteristics and cardiac and neural differentiation of human umbilical cord wharton's jellyderived mesenchymal stem cells. Stem Cell Int. 2016;2016:1-12.

15. Zhao Y, Waldman SD, Flynn LE. The effect of serial passaging on the proliferation and differentiation of bovine adiposederived stem cells. Cells Tissues Organs. 2012;195(5):414-27.

16. Antoninus AA, Widowati W, Wijaya L, Agustina D, Puradisastra S, Sumitro SB, et al. Human platelet lysate enhances the proliferation of Wharton's jelly-derived mesenchymal stem cells. BGM. 2015;7:8797.

17. Lee KS, Cha SH, Kang HW, Song JY, Lee $\mathrm{KW}$, Ko KB, et al. Effects of serial passage on the characteristics and chondrogenic differentiation of canine umbilical cord matrix derived mesenchymal stem cells. Asian-Australasian J Anim Sci. 2013;26(4): 588-95.

18. Safwani WK, Makpol S, Sathapan S, Chua KH. Alteration of gene expression levels during osteogenic induction of human adipose derived stem cells in long-term culture. Cell and tissue banking. 2013;14(2):289-301.

19. Zaim M, Karaman S, Cetin G, Isik S. Donor age and long-term culture affect differentiation and proliferation of human bone marrow mesenchymal stem cells. Ann Hematol. 2012;91(8):1175-86. 